\title{
Phenolic compound profiles and antioxidant activity of Ruta chalepensis $L$. leaves, a spontaneous medicinal herb: influence of harvest zone (Western Algeria)
}

\author{
EL-Kadi Fatima Zohra ${ }^{1 *}$, Kanoun Khedoudja ${ }^{2}$, Trouzine Amina ${ }^{3}$, Tehami Wafaa ${ }^{4}$, \\ Lebga Houaria ${ }^{5}$, Boumaza Nawal ${ }^{6}$, Harir Noria ${ }^{7}$ \\ ${ }^{1,3,5,6}$ Biotoxicology Laboratory, Biology Department , Faculty of Natural Sciences and Life ,Djillali Liabes \\ University of Sidi-Bel-Abbes, BP No. 89 Sidi-Bel-Abbes 22000 Algeria. \\ ${ }^{2,7}$ Laboratory of Molecular Microbiology Health and Proteomics, Biology Department , Faculty of Natural \\ Sciences and Life,Djillali Liabes University of Sidi-Bel-Abbes, BP $N^{\circ}$. \\ 89 Sidi-Bel-Abbes 22000 Algeria. \\ ${ }^{4}$ Saharan Natural Resources Laboratory, Department of Biology, \\ Faculty of Nature and Life Sciences, Ahmed Draia Adrar University, Algeria \\ *Email: elkadifatimazohra@yahoo.fr \\ Received : 03.03.2021 ; Revised: 22.04.2021 ; Accepted : 25.04.2021
}

\begin{abstract}
Natural plant extracts contain a variety of phenolic compounds, to which various biological activities are attributed. Ruta chalepensis, known as "Fidjel", is widespread in the Algerian territory, which was selected in order to estimate its content of secondary metabolites (phenolic compounds, flavonoids, tannins), and its antioxidant activity (DPPH, FRAP). For this purpose, two methanolic extracts were prepared from the leaves of this plant, harvested from two different areas: Tessala mountains (Sidi-Bel-Abbes town) and Taougrite mountains (Chlef town), which crude extract yields are around of $12.4 \%$ and $20.1 \%$ respectively. The quantitative estimation of the different secondary metabolites showed that the methanolic extract of Tessala mountains (MER $\left.{ }_{T E S}\right)$ is the richest in polyphenols (10.65 $\pm 0.67 \mathrm{mg} \mathrm{GAE} / \mathrm{g}$ ), flavonoids (31.16 $\pm 0.55 \mathrm{mg} \mathrm{CE} / \mathrm{g}$ ), hydrolyzable tannins (0.78 $\pm 0.02 \mathrm{mg} C \mathrm{CE} / \mathrm{g}$ ), and in condensed tannins $(2.75 \pm 0.10 \mathrm{mg} C E / \mathrm{g})$. However, an antioxidant activity evaluation of the two extracts showed that, both fractions are active with a maximum $I C_{50}$ of $68.41 \pm 9.98 \mu \mathrm{g} / \mathrm{ml}$ in $\left(M E R_{T E S}\right)$. On the other hand, the extract from that of the Taougrite Mountains $\left(M E R_{\text {TAO }}\right)$ shows a stronger reducing activity than (MER $\left.{ }_{T E S}\right)$; the difference remains not significant. In conclusion, the plant harvesting area, and the bioclimatic conditions might influence the Rutaceae leaf extracts content and quality of the same family.
\end{abstract}

Keywords: DPPH, FRAP, methanolic extract, Ruta chalepensis, secondary metabolites, yield.

\section{INTRODUCTION}

Since the beginning of humanity, people have been depending on plants to provide their vital necessities, thus the important role of plants as a good source of medicines (Sabitha Rani et al., 2019). In modern medical aspects, various plants or plant-based materials have attracted a great focus on the potential drug candidate development/ extraction, particularly for the non-communicable diseases treatment such as diabetes mellitus and cancer, etc. (Bhowmik, 2019). The active principles of medicinal plants are often linked to the productions of secondary metabolites, which are widely used in therapy, such as preventive antiinflammatory, antimicrobial, antiseptic, diuretic agents, essentially antioxidant agents which defend against oxidative stress (Bourgaud et al., 2001; Kar,
2007). Phenolic compounds, essential oils and other secondary metabolites represent high value molecules, used in the pharmaceutical, cosmetic and food industries. The antioxidant activities of these products have been reported in numerous studies around the world (Bouzouita et al., 2008). The Ruta chalepensis plant, belonging to the Rutaceae family is very rich in secondary metabolites, which explains its biological activities: antifungal, antioxidant and anti-inflammatory (Gonzalez-Trujano et al., 2006; Raghav et al.,2006; Al-Said et al.,1990). This specie is spontaneous, widely distributed in North Africa, particularly in Algeria; where it is known as Fidjel.

The objective of our study is to evaluate in vitro the antioxidant activity, as well as, the content of total phenolic compounds, flavonoids, 
hydrolyzable and condensed tannins of Ruta Chalepensis methanolic extracts, collected before the flowering period. Sampling was undertaken in two different western Algeria areas, (Tessala mountains in Sidi-Bel-Abbes region and Taougrite mountains in Chlef region) characterized by different bioclimatic conditions with the purpose to assess whether the different climatic conditions may influence the bioactive compound content.

\section{MATERIALS AND METHODS}

\section{Plant material}

Ruta Chalpensis was harvested in February 2018 in two different, areas: Tessala mount, which is located at $15 \mathrm{~km}$ northwest of the Sidi-Bel-Abbes city and the Taougrite mountain of the Chlef city. Bioclimatic data for the two regions are listed in (Table 1).

The leaves were washed in running water, and then dried at room temperature and away from light. The samples were then crushed and sieved to obtain a homogeneous granular structure, and stored in glass vials for further analysis (Fig. 1).

\section{Preparation of methanolic extracts}

The powdered Ruta Chalepensis leaves (10 g) were extracted with $100 \mathrm{ml}$ of $80 \%$ methanol, under agitation for 24 hours at room temperature (Majheniè et al., 2007). The mixture was filtered and then concentrated using a rotavapor (Heidolph instruments), to obtain two extract: $\mathrm{MER}_{\mathrm{TES}}=$ methanolic extract of Ruta from Tessala mount; MER $_{\text {TAO }}=$ methanolic extract of Ruta from Taougrite mount.

\section{Determination of secondary metabolites Total phenols}

The total phenol content of the extracts was determined by the Folin-Ciocalteu method (Qusti et al., 2010). $200 \mu \mathrm{l}$ of the extract was mixed with $1 \mathrm{ml}$ of freshly prepared Folin-Ciocalteu reagent (ten times diluted), and $0.8 \mathrm{ml}$ of $7.5 \%$ sodium carbonate $\left(\mathrm{Na}_{2} \mathrm{CO}_{3}\right)$ has been added. The mixture was incubated at room temperature for 30 minutes, and the reading was taken against a blank using a spectrophotometer at $765 \mathrm{~nm}$. Phenol concentration in each sample was calculated against a calibration curve with gallic acid at different concentrations. The results are expressed as milligrams gallic acid equivalent per gram of dry matter (mg GAE/g d.w).

\section{Flavonoids}

The flavonoid content of the extracts was determined using the aluminum trichloride colorimetric method (Kim et al., 2003). An amount of $500 \mu \mathrm{l}$ of the extract was mixed with $1.5 \mathrm{ml}$ of distilled water, and subsequently with $0.3 \mathrm{ml}$ of a $5 \%$ sodium nitrite solution $\mathrm{NaNO}_{2}$. After five minutes, $3 \mathrm{ml}$ of a $10 \% \mathrm{AlCl}_{3}$ solution was added. After $6 \mathrm{~min}, 1 \mathrm{ml}$ of $4 \% \mathrm{NaOH}$ was added. After five minutes the whole mixture was stirred with a vortex. The absorbance was measured at $510 \mathrm{~nm}$. Quercetin was used as standard for the calibration curve. Total flavonoids contents are expressed as, mg quercetin equivalent/g of dry matter (mg CE/g d.w).

\section{Condensed tannins}

This determination rate method of the condensed tannins is based on the condensation of polyphenolic compounds with vanillin in an acidic medium, which will give a brown compound. For the determination of condensed tannins, $0.1 \mathrm{ml}-0.5$ $\mathrm{ml}$ extracts were placed in tubes and then $3 \mathrm{ml}$ of $4 \%(\mathrm{w} / \mathrm{v})$ vanillin in methanol are added. After vigorous stirring $1.5 \mathrm{ml}$ of concentrated $\mathrm{HCl}$ was immediately added and stirred again. Absorbance was measured at $500 \mathrm{~nm}$ after 20 min of incubation (Julkunen-Titto,1985).The calibration curve was prepared under the same conditions, using catechin as standard and the results are expressed as $\mathrm{mg}$ catechin equivalent/g dry matter (mg CE/g).

We have adopted the vanillin method with $\mathrm{HCl}$. Which depends on the vanillin reaction with the terminal flavonoid group of condensed tannins, with the red complexes formation, this is explained by the characteristic of tannins to transform into red colored anthocyanidols by the reaction with vanillin. The content of condensed tannins was determined by the vanillin method described by (Julkunen-Titto,1985). A volume of 50 il of each extract was added to 1500 il of the $4 \%$ vanillin/ methanol solution and mixed vigorously. Then, 750 ì volume of concentrated hydrochloric acid $(\mathrm{HCl})$ was added. The obtained mixture was allowed to react at room temperature for $20 \mathrm{~min}$. The absorbance was measured at $550 \mathrm{~nm}$ against a control. Various concentrations between 0 and 1000 $\mu \mathrm{g} / \mathrm{ml}$ prepared from a catechin stock solution, will be used to trace the calibration curve. 


\section{Hydrolyzable tannins}

The hydrolyzable tannins determination was performed by the Mole and Watrman method (1987), based on a reaction with ferric chloride. The tannic extract mixture with the ferric chloride reagent produces a blue-black coloration in the presence of gallic tannins; and a green-brown coloration in the presence of catechic tannins, from which the $(\mathrm{Fe} 3+)$ ions are formed. To accomplish this, $1 \mathrm{ml}$ of the extract was added to $3.5 \mathrm{ml}$ of a $0.01 \mathrm{M} \mathrm{Fe} 1_{3}$ solution in $0.001 \mathrm{M} \mathrm{HCl}(\mathrm{V} / \mathrm{V})$. The mixture was vigorously mixed, and the optical density was read at $660 \mathrm{~nm}$ with a spectrophotometer. The hydrolyzable tannins content in the extracts was calculated from a calibration curve, carried out with gallic acid, under the same experimental conditions as the tested samples

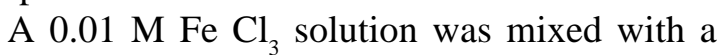
$0.001 \mathrm{M}(\mathrm{v} / \mathrm{v}) \mathrm{HCl}$ solution. $3.5 \mathrm{ml}$ of this solution was added to $1 \mathrm{ml}$ of extract. After 15 seconds, the absorbance was measured at $660 \mathrm{~nm}$.

The hydrolyzable tannins are expressed by the following formula:

$\mathrm{H} \mathrm{T}(\%)=($ Abs $\times \mathrm{M} \times \mathrm{V}) / \mathrm{E}$ mole $\mathrm{x} \mathrm{W}$

With: HT: hydrolysable tannins, Abs: absorbance, E mole: 2169 of gallic acid (constant expressed in mole), M: mass $=300$, V: volume of the used extract, $\mathrm{W}$ : weight of the sample. The results are expressed as milligram gallic acid equivalent per gram of dry extract (mg GAE/g DE).

\section{Antioxidant activity DPPH Test}

In the presence of free radical scavengers, the purple-colored DPPH (2,2-diphenyl-1picrylhydrazyl) is reduced to yellow-colored 2,2diphenyl-1-picrylhydrazine (Maataoui et al., 2006 and Molyneux, 2004).

The free radical scavenging activity of plant extracts was determined according to (Benhammou et al., 2009). A volume of 50 ìl of different concentrations of each extract was added to 1.95 $\mathrm{ml}$ of the freshly prepared DPPH methanolic solution ( $25 \mathrm{mg} / \mathrm{l})$. The negative control, were prepared in parallel, by mixing 50 il methanol with $1.95 \mathrm{ml}$ of a methanolic DPPH solution, at the same concentration. After incubation in the dark for 30 minutes at room temperature, the absorbances of each sample and negative control were read at 515 $\mathrm{nm}$ using a spectrophotometer. The reactions were repeated three times for each dilution, and then the value mean of the percentage inhibition of scavenging activity for DPPH was taken.

\section{Calculation of inhibition percentages of DPPH}

We calculate the inhibition percentages by the following formula :

$\mathrm{I} \%=((\mathrm{Ca}-\mathrm{Ta}) / \mathrm{Ca}) \times 100$. With: Ca: the control absorbance; Ta: the test absorbance performed.

All tests were performed in triplicate. The methanolic extracts kinetics reactions and ascorbic acid with DPPH were recorded at each examined concentration. The concentrations of the different extracts and ascorbic acid, as a function of the percentages of inhibited DPPH, were graphed at the end of the reactions to obtain the $I C_{50}$ index.

$I C_{50}$ or $50 \%$ inhibitory concentration is the test sample concentration required to reduce $50 \%$ of the DPPH radical. The $I C_{50}$ was graphically calculated by the linear regressions of the graphical representations of the inhibition percentages as a function of different concentrations of the fractions tested.

\section{FRAP Test (Ferric Iron Reducing Power)}

The principle is based on the ferric iron reduction reaction $\left(\mathrm{Fe}^{3+}\right)$, present in the $\mathrm{K}_{3} \mathrm{Fe}(\mathrm{CN})$ ${ }_{6}$ complex to ferrous iron $\left(\mathrm{Fe}^{2+}\right)$ by an antioxidant, the reaction is revealed by the change of the yellow color of ferric iron $\left(\mathrm{Fe}^{3+}\right)$ to the blue-green color of ferrous iron $\left(\mathrm{Fe}^{2+}\right)$.The intensity of this coloration is measured by spectrophotometry at $700 \mathrm{~nm}$ (Chung et al., 2002).

The protocol established by (Oyaizu et al.,1986) was adopted, which consists of taking $0.5 \mathrm{ml}$ of each extract, at different concentrations and mixing them with $1.25 \mathrm{ml}$ of a $0.2 \mathrm{M}$ phosphate buffer solution ( $\mathrm{pH}=6.6)$ and $1.25 \mathrm{ml}$ of a $1 \%$ potassium ferricyanide solution $\mathrm{K}_{3} \mathrm{Fe}(\mathrm{CN})_{6}$. The mixture was incubated at $50^{\circ} \mathrm{C}$, for $20 \mathrm{~min}$, and then cooled at room temperature. $2.5 \mathrm{ml}$ of $10 \%$ trichloroacetic acid was added to stop the reaction, and then the tubes are centrifuged at $3000 \mathrm{rpm}$ for $10 \mathrm{~min}$. Then $1.25 \mathrm{ml}$ of the supernatant added to $1.25 \mathrm{ml}$ of distilled water and $250 \mathrm{ml}$ of $0.1 \%\left(\mathrm{Fe} \mathrm{Cl}_{3}\right)$ solution. The absorbances read spectrophotometrically at a wavelength of $700 \mathrm{~nm}$. The positive control was 
represented by an antioxidant standard solution; the ascorbic acid, the absorbance of which was measured under the same conditions as the samples. The iron $\left(\mathrm{Fe}^{3+}\right)$ reducing activity determination was performed in triplicate.

\section{Statistical analysis}

The results are expressed in the form of the mean and their standard $(\mathrm{X} \pm \mathrm{ES})$. Statistical analysis of the data is conducted using Microsoft Excel version 2010 software. The statistical analysis of the different groups data; was carried out by the Student test " $\mathrm{t}$ "; this parametric statistical test is suitable for a comparative analysis between the means of the experimental samples, and that of the control group. In all cases, a p value $<0.05$ was considered significant.

\section{RESULTS AND DISCUSSION}

\section{Extractions yield}

The Ruta chalepensis leaves crude extract yields changed according to the stations (Table 2). The highest yields were measured in the plant leaves of the Taougrite mountains MER $_{\text {TAO }}$ (20.1\%) whereas in Tessala MER TES $_{\text {in }}$ were $12.4 \%$.

The difference in yield rate obtained was due before hand to the solvent used on the one hand and on the other hand, to the richness of Ruta chalepensis in methanol-soluble substances. Indeed, studies have indicated that a ratio of methanol $70 \%$ is generally used in the flavonoids extraction, phenol acids and their derivatives; and a wide range of biomolecules (Al-Farsi and Lee, 2008). The results of (Al-Said et al.,1990) on $R$. chalepensis, gave a crude extract yield of the whole aerial parts with $3.75 \%$, this yield is clearly much lower than that obtained in our study, this may be

Table 1: Climatic features of the study areas

\begin{tabular}{lcccc}
\hline Characters & Longitude & Latitude & Altitude & Climate \\
\hline Tessala & $00: 76408^{\circ}$ & $35: 26978^{\circ}$ & $1061 \mathrm{~m}$ & Semi-arid dry and cold \\
Taougrite & $0^{\circ} 5522222$ & $36^{\circ} 1423922$ & $528 \mathrm{~m}$ & Mediterranean with hot summer \\
\hline
\end{tabular}

Table 2: Crude extracts yields from Ruta chalepensis leaves.

\begin{tabular}{lc}
\hline Samples & Yield (\%) \\
\hline MER $_{\text {TES }}$ & 12.4 \\
MER $_{\text {TAO }}$ & 20.1 \\
\hline
\end{tabular}

g of dry matter, while Ghazghazia et al. (2013) have reported that, the $R$. chalepensis leaves polyphenol contents are $12.82 \mathrm{mg}$ GAE/g of dry matter. In another study carried out by Shuib et al. (2015), the Ruta angustifolia species registered a content of $18.89 \mathrm{mg} \mathrm{GAE} / \mathrm{g}$. 
On the other hand, the tested plant flavonoid content remained higher compared to other researches performed by Khlifi et al. (2013) who reported the Ruta chalepensis methanolic extract aerial part flavonoid content to be around $12.78 \pm$ $0.08 \mathrm{mg}$ EAG/g of dry matter. While Bettaieb et al. (2012) registered a content of $6.50 \mathrm{mg} \mathrm{QE} / \mathrm{g}$ of hydro-methanolic extract $(80: 20)(\mathrm{V}: \mathrm{V})$. This signifies that the flavonoid content varied according to the used extraction solvent.

\section{Condensed and hydrolyzable tannins content}

The condensed and hydrolyzable tannins quantification is shown in (Fig.3). Our results confirm that, the plant extract from the Tessala mountains is slightly rich in hydrolyzable $(\mathrm{p}<0.05)$ and condensed $(\mathrm{p}<0.01)$ tannins, compared to that from the Taougrite mountains. In general, the chemical families detected in our experimentation, confirmed the researches carried out on various origins species (Saudi Arabia, Turkey, Jordan, Algeria, India, Morocco and Oman) (El-Sayed et al., 2000; Gunaydin and Savci, 2005; Shehadeh et al., 2007; Haddouchi et al.,2013; Raaman et al., 2014; Al-Brashdi el al., 2016; Daoudi et al., 2016).

Indeed, the presence of these secondary metabolites can explain various biological activities: protective against biotic and abiotic aggressions, antifungal, antioxidant, phytotoxic, abortive, anti-allergic, anti-tumoral, anticancer, neuroprotective, antispasmodic, cytotoxic, antibacterial, anti-inflammatory, antiviral and insecticides (Conti et al.,2013; Shuib et al., 2015; Chaibeddra et al., 2016; Daoudi et al.,2016).

\section{Antioxidant activity \\ DPPH (2.2'-diphenyl-1-picrylhydrazyl)}

The results shown in the figure 4 , illustrate the percentages of the antiradical activity of the two Ruta chalepensis L. extracts shows that MER exhibits the highest inhibition percentage of order $85.6 \%$ at maximum concentration $(250 \mu \mathrm{g} / \mathrm{ml})$,

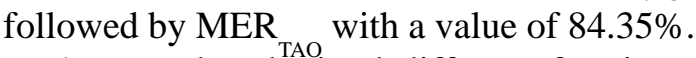

Among the obtained different fractions, the MER fraction represents the most active extract, its $I C_{50}^{\text {TES }}$ was $68.41 \pm 9.98 \mu \mathrm{g} / \mathrm{ml}$, followed by the $\mathrm{MER}_{\mathrm{TAO}}$ fraction with an $I C_{50}$ around $70.6 \pm 12.12$ $\mu \mathrm{g} / \mathrm{ml}$. Compared to the standard antioxidant ascorbic acid, both fractions are more active. The difference between the $I C_{50}$ of the tested extracts was not statistically significant (Fig.5).

Both extracts showed significant antioxidant capacity. According to Abou Zeid et al.(2014), phenolics such as flavonoids, phenolic acids, tannins and furocoumarins directly contribute to the plant antioxidant capacity. Turkmen et al. (2007) noted that polyphenols appear to be effective hydrogen donors to the DPPH radical, due to their chemical structure. Works carried out by Kang et al. (2003) suggested that, the polar molecules present in the plant extracts contribute to the antioxidant activity increase. This is generally due to the synergy between the different existing antioxidant compounds. Similarly, studies by Ouerghemm et al. (2016), which were performed on the $R$. chalepensis flowers methanolic extract from two different provenances (wild and cultivated), revealed that the antioxidant potential was quite high in the plant's aerial part with an $I C_{50}$ in the range of $23.73 \mathrm{ig} / \mathrm{ml}$ for the wild flowers and $28.48 \mathrm{ig} / \mathrm{ml}$ for the cultivated $R$. chalepensis flowers. The study achieved by Ghazghazi et al. (2013) on the Ruta chalepensis antioxidant activity revealed a remarkable antioxidant capacity; $I C_{50}$ of the leaves wich was estimated at $35 \mathrm{ig} / \mathrm{ml}$. The antioxidant capacity seems to be influenced by the total polyphenols contents. The studies of Kacem et al. (2015) also showed that $R$. chalepensis possesses a fairly high antioxidant potential. Indeed, at a concentration of about $500 \mathrm{mg} / \mathrm{ml}$, the ethanolic extract decolors the DPPH and scavenges the free radicals with an inhibition rate of about $84 \%$.

\section{Iron reducing (FRAP)}

The reducing activity results clearly show that, MER ${ }_{\text {TAO }}$ exhibits the reduce power of $\mathrm{Fe}^{+3}$ ion more strongly in comparison with MRE TEs, the statistical analysis doesn't show a significant difference (P> 0.05) (Fig. 6). According to results obtained, the activity of our extracts is average, these results which synchronize with that of Djeridane et al. (2006), where they found that, the Ruta sp. phenolic extract activity was less important compared to the other ten plants studied at the same time, although the phenolic compounds content was important, this is generally due to the synergy between the different existing antioxidant compounds, which makes the activity not only concentration-dependent. The antioxidant activity depends on several factors, such 

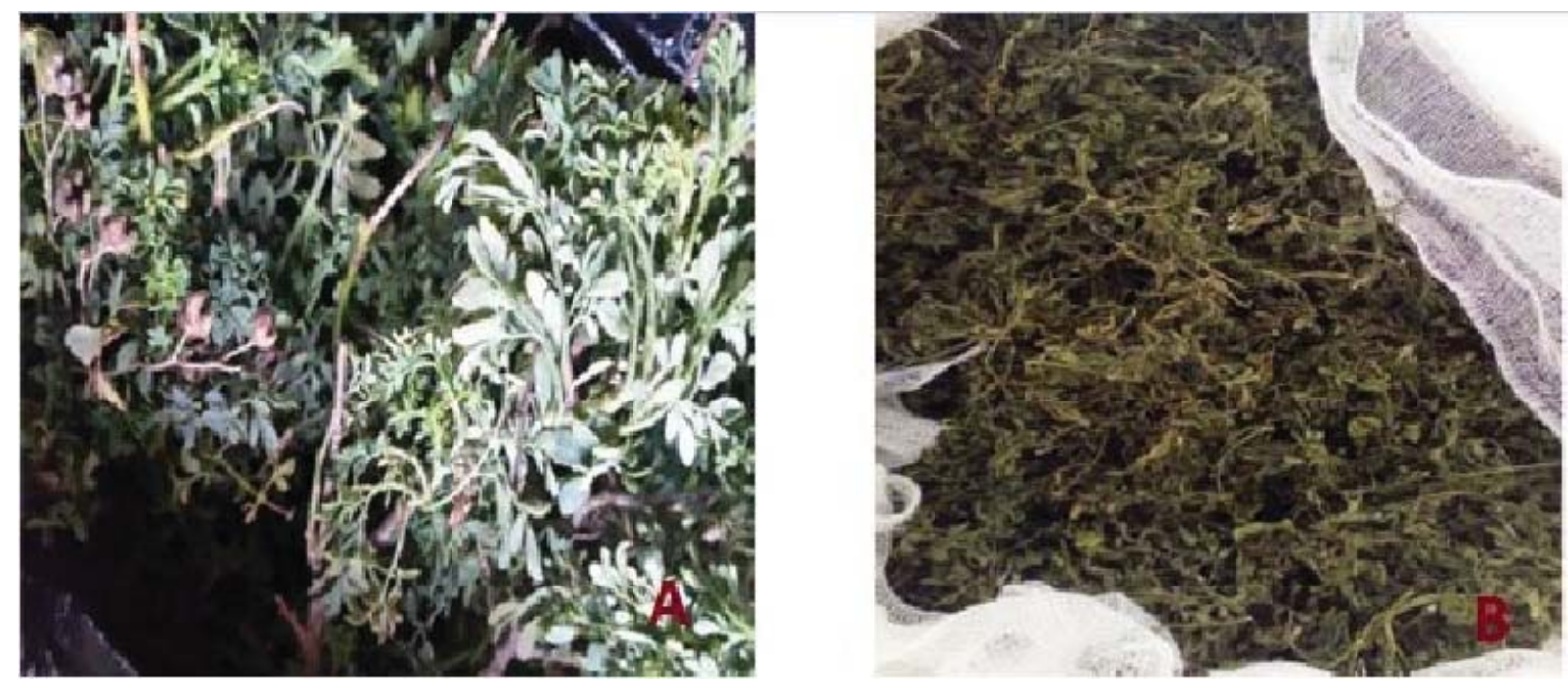

Fig. 1: Ruta chalepensis fresh plant (A) and after drying (B) (personal photo)
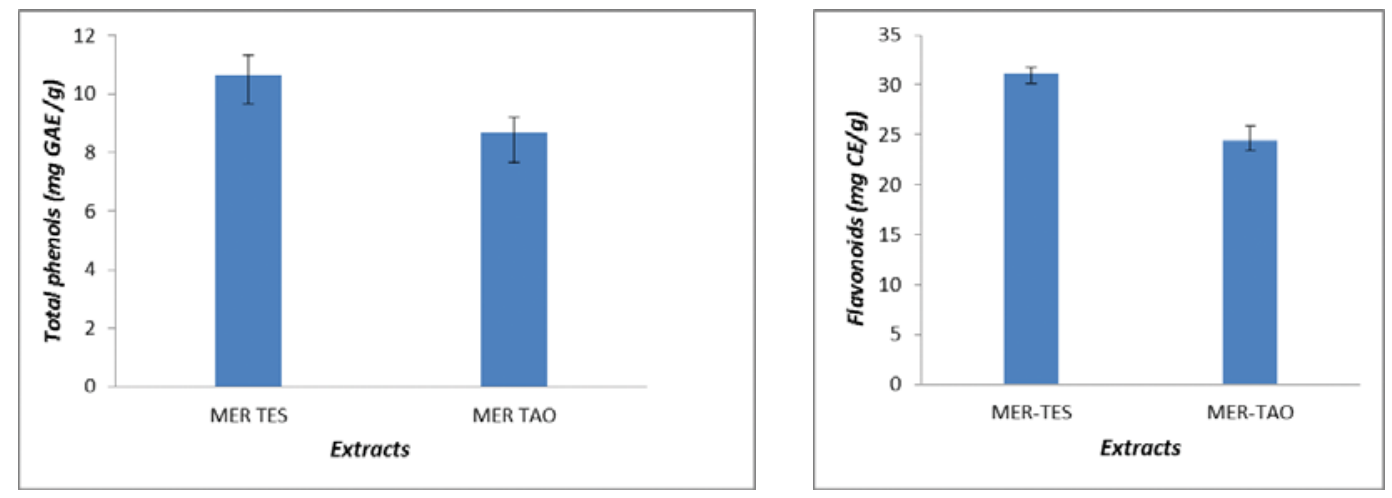

Fig. 2: Total phenols and flavonoids contents of Ruta chalepensis leaves extracts
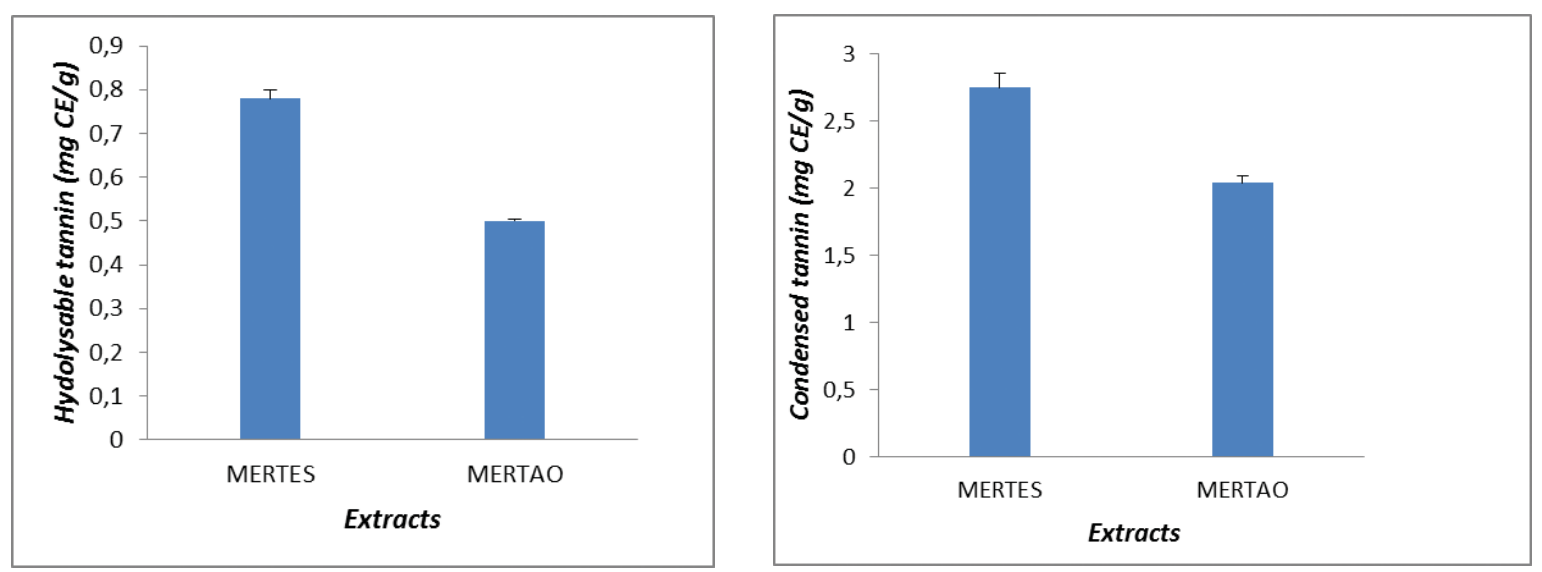

Fig. 3: Hydrolyzable and condensed tannin content of Ruta chalepensis leaves extracts. 
Phenolic compound profiles and antioxidant activity of Ruta chalepensis

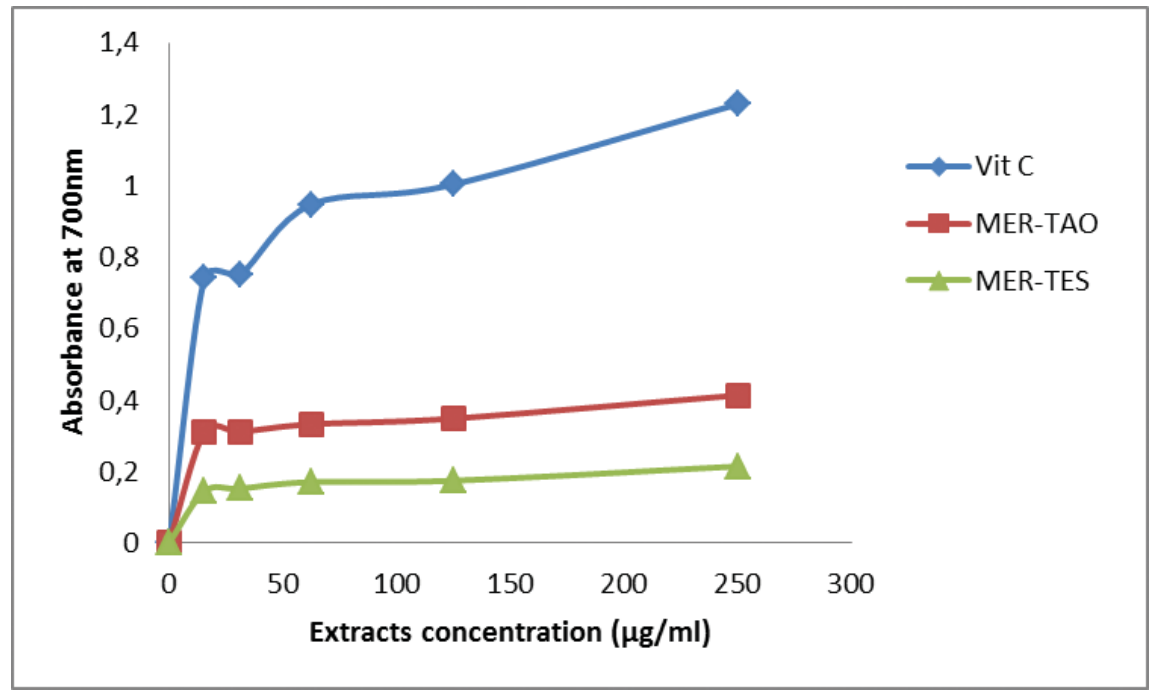

Fig. 4: Antiradical activity of Ruta chalepensis methanolic extracts

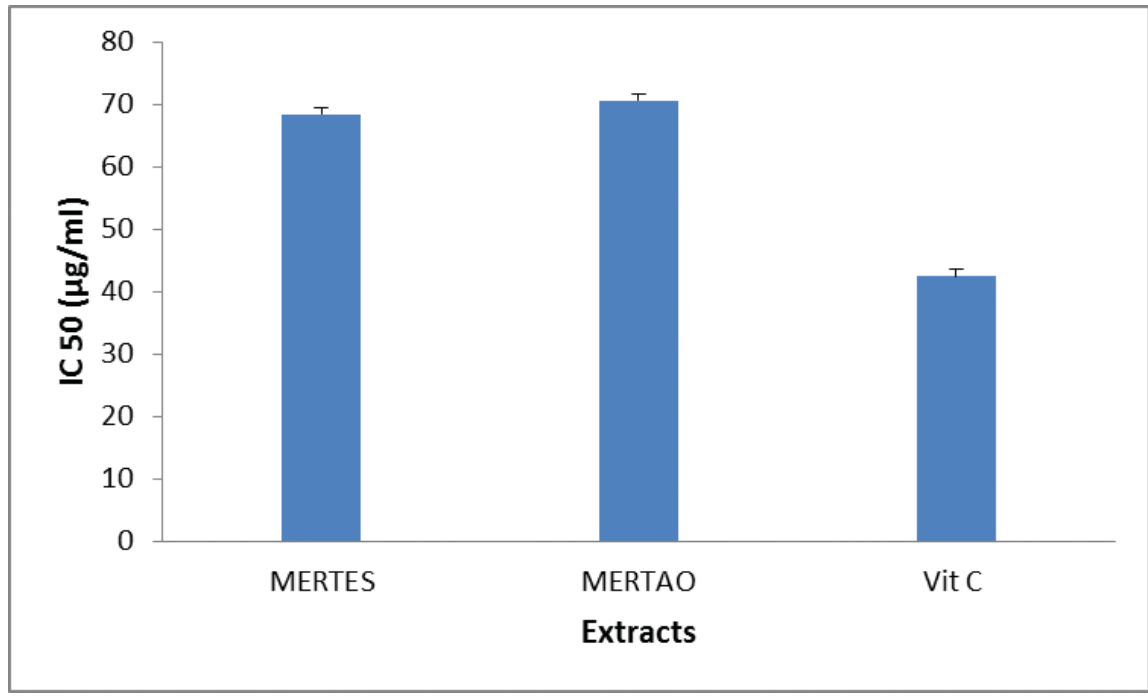

Fig. 5: Median inhibitory concentration of Ruta chalepensis extracts

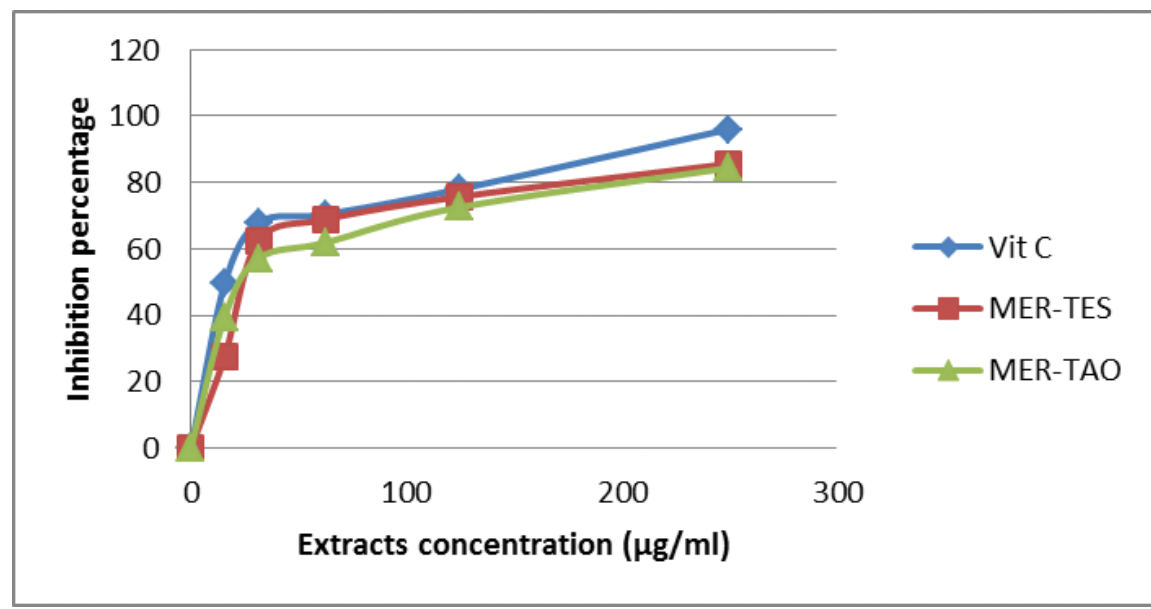

Fig .6: Antiradical activity potency of Ruta chalepensis extract 
as: the extract concentration, the evaluation method, the antioxidant sensitivity to the test temperature, the antioxidant's water -soluble or lipid-soluble nature ( Kadri, 2011 and Pukalskas, 2012).

\section{CONCLUSION}

From in vitro data it was concluded that the Ruta Chalepensis extract from the Tessala mountains was slightly rich in certain secondary metabolites and antioxidant elements, than that of the Taougrite mountains. The study has highlighted the influence of area harvest factor of plant on the extracts content and quality. In addition, an evaluation of the antioxidant activity of the Ruta chalepensis essences against DPPH and FRAP, and the spectral assay of the bioactive substances (polyphenols, flavonoids and tannins), showed that this Rutaceae exhibit an interesting antioxidant power suggesting their use in the food, in cosmetics and in the pharmaceutical industry.

\section{CONFLICT OF INTEREST}

The authors declare that they have no conflicts of interest with respect to the publication of this document.

\section{REFERENCES :}

Abou-Zeid, H.M. Bidak, L.M. and Goh, Y.M. 2014. Phytochemical screening and antimicrobial activities of some wild medicinal plants of the western Mediterranean coastal region Egypt. Int. J. Pharm. Sci. Res.,5 (10): 44454455.

Al-Brashdi, A.S. Al-Ariymi, H., Al Hashmi, M. and Khan, S.A. 2016. Evaluation of antioxidant potential, total phenolic content and phytochemical screening of aerial parts of a folkloric medicine, Haplophyllum tuberculatum (Forssk) A Juss. J. Coast. Life Med., 4(4): 315-319.

Al-Farsi, M.A and Lee,C.Y. 2008. Optimization of phenolics and dietary fibre extraction from date seeds. Food Chem., 108 (3): 977-985.

Al-Said, M.S., Tariq, M.M., Al-Yahya, A., Rafatullah, S., Ginnawi, O.T. and Ageel, A.M .1990. Studies on Ruta chalepensis, an ancient medicinal herb still used in traditional medicine. J Ethnopharmacol., 28(3):305312.
Atmani, D., Chaher, N., Barboucha, M., Ayouni, K., Lounis, H., Boudaoud, H., Debbache, N. and Atmani, D. 2009. Antioxydant capacity and phenol content of selected Algerian medicinal plants. Food Chem., 112 (2):303309.

Benhammou, N., Atik Bekkara, F. and Kadifkova, P.T. 2009.Antioxidant activity of methanolic extracts and some bioactive compounds of Atriplex halimus. Comptes Rendus Chimie., 12 (12): 1259-1266.

Bentabet, N., Boucherit-Otmani, Z. and Boucherit, K. 2007. Composition chimique et activité antioxydante d'extraits organiques des racines de Fredolia aretioides de la région de Béchar en Algérie. Phytotérapi .,12 :364371.

Bettaieb, A. Moujahed, N. and Ksouri, R. 2012.Secondary compounds characterization in some autochtonous species from a NorthEastern region of Tunisia. Options mèditerranèennes: New approaches for grassland research in a context of climate and socio-economic changes Series A. Séminaires Méditerranéens., $\mathrm{n}^{\circ}$ 102, Samsun (Turkey).

Bhowmik, D.2019. Aloe vera-Gift to mankind. International Journal of Minor Fruits, Medicinal and Aromatic Plants, 5 (1): 0106.

Bourgaud, F., Gravot, A., Milesi, S. and Gontier, E. 2001. Production of plant secondary metabolites: A historical perspective. Plant Sci., 161(5): 839-851.

Bouzouita, N., Kachouri, F., Ben Halima, M.K. and Chaabouni, M.M. 2008. Composition chimique et activités antioxydante, antimicrobienne et insecticide de l'huile essentielle de Juniperus phoenicea. Journal de la Société Chimique de Tunisie., 10 : 119125.

Chaibeddra, Z., Baaziz, N. and Zellagui, A. 2016. Ruta tuberculata Forsk: Phytochemical screening, total phenolic contents and antioxidant activity of crude coumarins and alkaloids extracts. Der Pharm Lett., 8 (6):212-216.

Chung, Y.C., Chang, C.T., Chao, W.W., Lin, C.F. and Chou, S.T. 2002. Antioxidative activity and safety of the 50 ethanolic extract from red bean fermented by Bacillus subtilis IMRNK1. J Agric food chem., 50 (8):2454-2458. 
Conti, B., Leonardi, M., Pistelli, L., Profeti, R., Ouerghemmi, I. and Benelli, G . 2013. Larvicidal and repellent activity of essential oils from wild and cultivated Ruta chalepensis L. (Rutaceae) against Aedes albopictus Skuse (Diptera: Culicidae), an arbovirus vector. Parasitol Res., 112(3) :991999.

Daoudi, A., Hrouk, H., Belaidi, R., Slimani, I., Ibijbijen, J. and Nassiri, L. 2016. Valorization of Ruta montana and Ruta chalepensis: Ethnobotanical study, phytochemical screening and Antibacterial activity. J Mater Environ Sci., 7 (3):926-935.

Djeridane, A., Yous, M., Nadjemi, B., Boutassouna, D., Stocker, P. and Vidal, N. 2006. Antioxidant activity of some Algerian medicinal plants extracts containing phenolic compounds. Food Chem., 97 (4): 654-660.

El Sayed, K., Al-Said, M. S., El-Feraly, F. S. and Ross, S. A. 2000. New Quinoline Alkaloids from Ruta chalepensis. J. Nat. Prod., 63(7):995-997.

Fakhfakh, N., Zouari, S., Zouari, M.M., Loussayef, C. and Zouari, N. 2012. Chemical composition of volatile compounds and antioxidant activities of essential oil, aqueous and ethanol extracts of wild Tunisian Ruta chalepensis L. (Rutaceae). J Med Plant Res., 6(4): 593-600.

Ghazghazia, H. Chediab, A., Abderrazakb, M. and Brahima, H. 2013. Comparaison des contenus en polyphénols et de l'activité antioxydante des extraits méthanoliques de quatre plantes collectées du nord de Tunisie. Microbiol Hyg Alim., Vol 25, $\mathrm{N}^{\circ} 73$ (4ème Journée GEDIV).

Gonzalez-Trujano, M.E. Carrera, D. VenturaMartinez, R. Cedillo-Portugal, E and Navarrete, A.2006. Neuropharmacological profile of an ethanol extract of Ruta chalepensis L. in mice. J Ethnopharmacol., 106 (1): 129-135.

Gunaydin, K. and Savci, S. 2005. Phytochemical studies on Ruta Chalepens (LAM.) LAMARCK. Nat. Prod. Res., 19(3): 203-210.

Haddouchi, F., Chaouche, T.M., Zaouali, Y., Ksouri, R., Attou, A. and Benmansour, A. 2013. Chemical composition and antimicrobial activity of the essential oils from four Ruta species growing in Algeria. Food Chem., 141 (1):253-258.
Hnatyszyn, O., Arenas, P., Moreno, A.R., Rondina, R. and Coussio, J.D. 1974. Plantas reguladoras de la fecundidad segun la medicina folklorica. Revista de la Sociedad Cientifica., 14: 37.

Hayouni, E., Abedrabba, M., Bouix, M. and Hamdi, M. 2007. The effects of solvent and extraction method on the phenolic contents and biological activities in vitro of Tunisian Quecus coccifera L. and Juniperus phoenicea L. fruit extracts. Food Chem., 105 (3): 11261134.

Julkunen-Tiitto, R. 1985. Phenolic constituents in the leaves of northern willows: Methods for the analysis of certain phenolics .J Agric food chem., 33 (2): 213-217.

Kacem, M., Kacem, I., Simon, G., Ben Mansour, A., Chaabouni, S., Elfeki, A. and Bouaziz, M. 2015. Phytochemicals and biological activities of Ruta chalepensis L. growing in Tunisia. Food Biosci., 12 (1):73-83.

Kadri, A., Zarai, A., Bekir, A., Gharsallah, N., Damak, M. and Gdoura, R. 2011. Chemical composition and antioxidant activity of Marrubium vulgare L. essential oil from Tunisia. Afr J Biotechnol., 10(9): 3908-3914.

Kang, D.G., Yun, C.K. and Lee, H.S. 2003. Screening and comparison of antioxidant activity of extracts of herbal medicines used in Korea. J. Ethnopharmacol., 87 (2-3): 231236.

Kar, A. 2007. Pharmaocgnosy and Pharmacobiotechnology. Revised-Expanded Second Edition. New Age International Limted Publishres, New Delhi. pp. 332-600.

Khlifi, D., Sghaier, R.M., Amouri, S., Laouini, D., Hamdi, M. and Bouajila, J. 2013. Composition and anti-oxidant, anti-cancer and anti-inflammatory activities of Artemisiaherba-alba, Ruta chalpensis L. and Peganum harmala L. Food Chem Toxicol., 55: 202-208.

Kim, D.O., Chun, O.K., Kim, Y.J., Moon, H.Y. and Lee, C.Y. 2003. Quantification of polyphenolics and their antioxidant capacity in fresh plums. J Agric Food Chem., 51 (22):6509-6515.

Ksouri, R., Megdiche, W., Falleh, H., Trabelsi, N., Boulaaba, M., Smaoui, A. and Abdelly, C. 2008. Influence of biological, environmental and technical factors on phenolic content and 
antioxidant activities of Tunisian halophytes. C R Biol., 331(11) :865-873.

Maataoui, B.S.,Hmyene, A. and Hilali, S. 2006.Activités anti-radicalaires d'extraits de jus de fruits du figuier de barbarie (Opuntia ficus indica). Leban Sci J., 7(1):3-8.

Majheniè, L. Škerget, M. and Knez, Ž 2007. Antioxidant and antimicrobial activity of guarana seed extracts. Food Chemistry, 104(3);1258-1268.

Mejri , J., Abderrabba, M. and Mejri, M. 2010. Chemical composition of the essential oil of Ruta chalepensis L: influence of drying, hydro-distillation duration and plant parts. Ind. Crops Prod., 32(3) : 671-673.

Merghache, S., Hamza, M. and Tabti, B. 2009. Etude phytochimique de l'huile essentielle de Ruta chalepensis L. de Tlemcen, Algérie. Afr Sci., 5(1): 67-81.

Mole, S. and Waterman, P.G. 1987. A critical analysis of techniques for measuring tannins in ecological studies: I. Techniques for chemically defining tannins. Oecologia., 72, (1):137-147.

Molyneux, P. 2004. The use of the stable free radical diphenyl picryl hydrazyl (DPPH) for estimating antioxidant activity. Songklanakarin J. Sci. Technol.,26 (2):211219.

Ouerghemmi, I., Rebey, I. B., Rahali, F.Z., Bourgou, S., Pistelli, L., Ksouri, R., Marzouk, B. and Tounsi, M.S. 2016. Antioxidant and antimicrobial phenolic compounds from extracts of cultivated and wild-grown Tunisian Ruta chalepensis. J Food Drug Anal., 25(2):350-359.

Oyaizu, M. 1986. Studies on products of browning reactions: Antioxidative activities of product of browning reaction prepared from glucosamine. Japanese Journal of Nutrition and Dietetics, 44(6): 307-315.
Pukalskas, A., Venskutonis, P.R., Salido, S., Waard, P. and Van Beek, T.A. 2012. Isolation, identification and activity of natural antioxidants from horehound (Marrubium vulgare L) cultivated in Lithuania. Food Chem., 130 (3):695-701.

Qusti, S., Abo-Khatwa, A.N. and Lahwa, M. A. 2010. Screening of antioxidant activity and phenolic content of selected food items cited in the holly Quran. Eur J Biol Sci., 2 (1):4051.

Raaman, N., Natarajan, P., Swaminathan, A., Balan, L. and Laxmanan, H. 2014. In vitro propagation, qualitative phytochemical analysis and antioxidant activity of Ruta chalapensis L. Med Plants, 6 (2):87-93.

Raghav, S.K., Gupta, B., Agrawal, C., Goswami, K. and Das, H.R. 2006.Anti-inflammatory effect of Ruta graveolens L. in murine macrophage cells. J Ethnopharmocol., 104 (1-2):234-239.

Sabitha Rani, A., Hajera Sana, G., Sulakshana, E., Shravya, P. and Keerti, M. 2019. Spilanthes acmella-an important medicinal plant. International Journal of Minor Fruits, Medicinal and Aromatic Plants, 5 (2): 1526.

Shehadeh, M.B., Afifi, F.U. and Abu-Hamdah, S.M. 2007. Platelet aggregation inhibitors from aerial parts of Ruta chalepensis grown in Jordan. Integr Med Insights, 2 (1): 35-39.

Shuib, N.A., Iqbal, A., Akmal Sulaiman, F., Razak, I. and Susanti, D. 2015. Antioxidant and antibacterial activities of Ruta angustifolia extract. J Teknol (Sciences and Engineering), 77(25):101-105.

Turkmen, N., Velioglu, Y. S., Sari, F. and Polat, G. 2007. Effect of extraction conditions were total polyphenol content and antioxidant Measured and antibacterial activities of black tea. Molecules, 12 (3):484-496. 